\title{
Invisible golden girls? Post-feminist discourses and female ageing bodies in contemporary television fiction
}

\section{Sofie Van Bauwel}

To cite this article: Sofie Van Bauwel (2017): Invisible golden girls? Post-feminist discourses and female ageing bodies in contemporary television fiction, Feminist Media Studies, DOI: 10.1080/14680777.2018.1409969

To link to this article: https://doi.org/10.1080/14680777.2018.1409969

曲 Published online: 11 Dec 2017.

Submit your article to this journal $₫$

Q View related articles $\asymp$

View Crossmark data $\complement 7$ 


\title{
Invisible golden girls? Post-feminist discourses and female ageing bodies in contemporary television fiction
}

\author{
Sofie Van Bauwel \\ Department of Communication Sciences, Ghent University, Ghent, Belgium
}

\begin{abstract}
The popular television series The Golden Girls (1985-1992) seems to be an exception in the history of the representation of third-age women femininities and bodies in television fiction. This series about four mature women living in the same house in Miami made ageing women visible in television representations. Older women are generally invisible in popular television fiction. Despite this absence, a discourse on ageing and femininities is present in all sorts of popular media texts. We will question post-feminist discourses on ageing bodies and femininities. Are the post-feminist claims regarding ageing bodies present in popular television fiction? Moreover, are these discourses represented by the portrayal of ageing bodies? We will analyse the representations of ageing femininities in television fiction labelled as "post-feminist television fiction."The series Sex and the City, Desperate Housewives, and Girls will be studied using a textual analysis to look for discourses on ageing female bodies and their particularities in relation to post-feminism. We distinguished a limited set of three sets of discourses (losing femininity, masking of ageing, and the wisdom of ageing) on ageing femininities. Although ageing feminine bodies are absent, a discourse on ageing, "good" ageing, and acceptance of ageing is present in the narration in all three series. The discourse on the masking of ageing, however, is predominant.
\end{abstract}

\section{KEYWORDS}

Ageing; television fiction; post-feminism; gender; femininity

\section{Introduction}

The contemporary popular television fiction shows Sex and the City, Desperate Housewives, and Girls are celebrated and even branded as post-feminist television. Sex and the City (19982004, HBO) - which at the time of its release was labelled a romantic comedy set in New York City-premiered in 1998 and was an instant international success. The US comedy-drama Desperate Housewives (2004-2012, ABC/Cherry Productions) premiered six years later and was also a story about several women-albeit this time not four girlfriends in New York, but a group of women living on the same street in a fictional town in the USA. Desperate Housewives was also an international success. In 2012, the comedy-drama Girls (2012-, HBO), which was about a group of four young women in their twenties in New York City, was also an instant hit. These three series all owe a debt to the popular sitcom The Golden Girls 
(1985-1992, NBC), which was the first successful series in the USA to focus on the lives of a group of women. Broadcasters' continued interest in television content that focuses on the lives of women can, of course, be linked to gender as one of the important markers for advertisers. As a target audience, women are addressed by stories "about themselves." However, The Golden Girls is an exception in the history of the representation of third-age women in North American television fiction, and Sex and the City, Desperate Housewives, and Girls portray women in different contexts and in changing ways. While The Golden Girls represented four mature women living in the same house in Miami and made ageing women visible in television representations, the show was an exception in terms of how ageing femininities are represented on television.

Older women are generally invisible in popular television fiction. Despite this absence, a discourse on ageing and femininities is present in all sorts of popular media texts. Strong statements on ageing and ageing bodies seem to be ubiquitous in various media representations. Some scholars even argue that the media industry is interested in ageing audiences due to economic factors and the potential of elderly audiences in the future of television programming (Robert Kubey 1980). Such arguments are used to explain the interest in the representation of ageing in, for example, Grace and Frankie (2015-, Netflix), an American comedy web television series that originally streamed on Netflix. Similarly, Imelda Whelehan and Joel Gwynne (2014) stress the "silver Tsunami" in advertising and popular discourses in film. However, as Whelehan and Gwynne (2014) point out, while some of these representations are celebrations of ageing (e.g., Grace and Frankie), most are representations of decline and deterioration as, for example, the character of Kitty Forman in That'70s Show (1998-2006, Fox), who embodied the loss of youth, beauty, and therefore life itself, or the older women in the series Orange Is the New Black (2013-, Netflix), who are represented as being in decline.

But what about post-feminist discourses on ageing bodies and femininities? Are the post-feminist claims about ageing bodies (e.g., all bodies are equal, beauty is everywhere, successful ageing, etc.) present in popular television fiction? Moreover, are these discourses represented by the portrayal of ageing bodies? Although discourses on the shame of ageing, successful ageing, the denial of ageing, body modifications, and anti-ageing have been articulated in popular television fiction (Kathleen Woodward 2006; Whelehan and Gwynne 2014), visual representations of the body seem to be lacking. In this research, we will analyse the representations of ageing femininities in contemporary television fiction labelled as "post-feminist television fiction." Sex and the City, Desperate Housewives, and Girls will be studied using a textual analysis to look for discourses on ageing female bodies and their particularities in relation to post-feminism. In this analysis, the material body is seen as more than a pre-cultural, pre-social object (Chris Barker 2008). Instead, the body is seen as being "loaded with cultural symbolism" (Anthony Synnot 2002, 1) and thus as a signifier referring to cultural prescriptions defining normality (Mary Kosut 2010; Heather Laine Talley 2013).

\section{Post-feminism and television fiction}

In the last 10 years, scholars have celebrated and critically examined the representation of femininities in contemporary television texts (e.g., Fien Adriaens and Sofie Van Bauwel 2014; Rebecca Brasfield 2006; Sean Fuller and Catherine Driscoll 2015; Yvonne Tasker and Diane Negra 2007), discussing the problematic concept of post-feminism and analysing television content that depicts women and femininities as the core of their narration (e.g., Kim Akass 
and Janet McCabe 2008; Elizabeth Kaufer Busch 2009; Lauren Decarvalho 2013; Meredith Nash and Ruby Grant 2015). According to Sean Fuller and Catherine Driscoll $(2015,259)$, post-feminism today is widely used to explain the "inadequacy of popular culture for representing feminism." Post-feminism has been defined as a "double entanglement," which refers to the coexistence of neoconservative values and liberal values or "burgeoning post-feminist culture" (Angela McRobbie 2004, 259). As Adriaens and Van Bauwel (2014) argue, some themes seem to be embedded in the discourse of post-feminist television content. Although post-feminist television includes multi-vocal themes, including empowerment, consumerism, (sexual) pleasure, individual choice, and independence, a renewed focus on the female body and humour are articulated in most of the contemporary post-feminist television texts. For example, Meredith Nash and Ruby Grant (2015) argue that while Girls and Sex and the City are both post-feminist texts, they differ in terms of how they narrate personal choice and feminine bodily management. Post-femininities are articulated in various ways and thus can be considered both apolitical and as potential texts for the political (Adriaens and Van Bauwel 2014; Nash and Grant 2015). Naomi Rockler $(2006,259)$ argues that post-feminist television series have an "invisible political dimension of gender" which she relates to the notions of empowerment and individualism. Besides the neo-liberal notions of individuality and agency, the "hegemony of the youthful postfeminist heterosexual ideal" (Ros Jennings and Maricel Oró-Piqueras 2016, 74) dominates popular cultural texts. As Rosalind Gill (2007) argues, the post-feminist ideology can be described as a "postfeminist sensibility" that consists of "broadly feminist sentiments" (Imelda Whelehan 2010) detached from the political roots of feminism, stressing an intertextual relationship with feminism and anchored in a consumption-based lifestyle (Whelehan 2010, 161). Imelda Whelehan $(2010,161)$ emphasizes that post-feminism "displays anxiety about ageing and physical decline, but also represents 'real' age as always deferred by health and beauty regimes." As Josephine Dolan and Estella Tincknell $(2012, x i)$ argue, there seems to be a new visibility of what they describe as "graceful agers."

Although post-feminist television series do not focus on ageing, post-feminism articulates certain discourses in relation to ageing, particularly ageing femininities. Paradoxically ageing bodies are sometimes seen as equal to young bodies-a discourse that stresses that beauty is everywhere (Rylee Dionigi, Sean Horton, and Josephine Bellamy 2011; Barbara Marchal and Stephen Katz 2012). Ageing can be successful and getting older is not the end of femininity per se. But Ros Jennings and Maricel Oró-Piqueras (2016) argue that there is no concern or space for postmenopausal women in a post-feminist discourse. The question still remains: are these themes of ageing, ageing bodies, and successful ageing represented in contemporary popular post-feminist television series, and if so, how?

\section{Representing ageing and gender}

It is clear that older people are not part of popular media representations; however, some scholars (Whelehan and Gwynne 2014) argue that the media industry has recently begun targeting seniors and thus elderly people are being portrayed more often. Nonetheless, ageing either is not represented or is depicted in a very narrow and stereotypical way. As Tim Healey and Karen Ross (2002) point out in their audience study on older viewers' perceptions of the representation of age in the UK, this specific audience finds they either are not represented or are depicted with stereotypes in all television genres. Healey and Ross 
stress the lack of sensitivity with ageing in depictions of the elderly on television. According to previous analyses of the representation of ageing women on television (Myrna Hant 2007; Maricel Oró-Piqueras and Anita Wohlmann 2015; Kristina Wallander 2013; Yirpi Ylänne 2012), ageing women are mostly represented in daytime soap operas and sitcoms. According to Myrna Hant (2007), mature women are only portrayed as "the other," that is, as pathetic or frail or as mothers or grandmothers.

Humour seems to be the key element in the representation of ageing femininities. As Rosie White (2014) states, age — like race, class, and sexuality — can result in double discrimination when it intersects with gender. She studies the representation of older women in British television comedies and argues that the same representations are often repeated: older ladies are depicted as gossipers, asexual spinsters, or "battle-axe figures feared by their husbands." However, she also examines different representations, as in the sitcom One Foot in the Grave (1990-2000, BBC), where death and traditional gender roles are mocked. Such exceptions aside, the intersection of femininities and ageing is limited in television content and often is depicted only in the context of humour. As White's analysis shows, the ageing femininities are represented as transgressive, but at the same time are also policed and stereotyped as "inappropriate." In this context, Rosie White (2014) refers to "cultural ambivalences" in relation to the representation of ageing femininities in television comedy. She also criticizes the way series such as The Golden Girls represent "girls" who are "young-old" women of pensionable age, but are healthy, active and not "old-old" (White 2014, 156).

Another recent discourse on ageing is linked to consumerism and the new identities around ageing bodies and self-care (Mike Featherstone and Mike Hepworth 1995; Eileen Kennedy and Pirkko Markula 2011; Jacqueline Low and Susanne Dupuis-Blanchard 2013; Julia Rozanova 2010). While notions of maturity and senior citizenry as market and lifestyle industries can be interpreted as positive images of ageing, they can also articulate an idealized culture of "agelessness" (Stephen Katz 2000). According to Kristina Wallander (2013, 92), the dominant discourse in the past concerning older people was one of "decline and loss," whereas now a greater range of representations exists in popular culture, including portrayals of successful ageing (Karen Lövgren 2012). Such representations of "good ageing" are often signified by depictions of healthy bodies that are in shape and articulate exceptional embodiment (Amy Cuddy, Michael Norton, and Susan Fiske 2005). This new stereotype is often embodied by celebrities and the way they are represented onscreen and off-screen. Furthermore, the new stereotype implies the construction of a third-age identity (Sadie Wearing $2012 ; 2015)$ that differs from the very narrow and negative stereotype of ageing as decline and loss. For Jennings and Oró-Piqueras $(2016,81)$, this glamourous ageing women's presence acts "as a fetish against the 'toxicity' of decay and decline," and can be described as a "cultural celebration of the physiological exception" (80). These "successful" representations of older people contrast with the "not so perfect" representations of younger bodies (Claire Perkings 2014). For example, Girls, which is celebrated as a post-feminist television text, depicts "imperfect" bodies in an unflattering and sometimes raw manner. "Ideal bodies" that represent society's beauty standards and stereotypical femininity are not present in Girls (Serena Daalmans 2013; Decarvalho 2013). As Jessica Ford (2016, 1035) stresses, "Girls presents a kind of female nudity that is aesthetically and politically different from the glossy, eroticized female nudity of other cable series like Game of Thrones, Sex and the City, and True Blood."While the ideology of "successful ageing" is often articulated as "sexy but not sexual" 
(Jennings and Oró-Piqueras 2016, 78), Stephen Katz and Barbara Marshall (2003) argue that the neo-liberal discourse on ageing also includes an active sex life in old age.

\section{Analysing discourses on ageing}

We analysed three popular so-called post-feminist television series that have been watched by a large international audience (Sex and the City, Desperate Housewives, and Girls) with respect to the discourses of ageing in relation to gender and we examined the representations of ageing femininities in each series. Sex and the City, the oldest of the three series, centres on four white middle- or upper-middle-class women in their thirties living in Manhattan, New York. The storylines develop around their friendship and are told from the perspective of the narrator, who is one of the key characters. Their lives, work, relationships, and love/sexual lives are portrayed. Girls, the newest of the three series, depicts a similar setting. The show is a cable television series written by Lena Dunham and focuses on four women in their twenties living in Brooklyn, New York. Like Sex in the City, Girls follows four middle-class, educated white women living their lives. As Nash and Grant $(2015,979)$ explain, Girls depicts the "explorations of what it is like to be a young white woman in contemporary US society." Desperate Housewives, set in the fictional suburban town of Fairview, differs somewhat from the previous two series. Desperate Housewives follows the lives of a group of women over 13 years. Also unlike the previous two shows, Desperate Housewives is not told from the perspective of one of the main characters. Instead, the story is told through the eyes of their neighbour who committed suicide in the pilot episode.

We delineated our sample of analysed episodes by focusing on episodes in which ageing assumes an element in the narrative position and was part of the major storyline of that specific episode. Our selection expresses the need to understand the discourses on ageing in the selected episodes. By using a textual analysis focusing on the discourses on ageing, we analysed five episodes of Sex and the City (SATC) (Season 2 episode 3(SO2E3), ${ }^{1}$ SO2E17, SO3E3, SO5E3 and SO6E12), three episodes of Girls (G) (SO1E6, SO3E9 and SO4E7) and five episodes of Desperate Housewives (DHW) ${ }^{2}$ (SO5E1, SO6E1, SO6E16, SO7E7 and SO8E22). We used a textual analysis (Larsen 2002; McKee 2003) focusing on the understanding of latent meanings in the selected episodes of post-feminist television series. We analysed how the theme of ageing and the intersection with gender, more specifically with femininity, is represented in these episodes (we analysed the episodes fully). We selected our sample selectively since the theme is only dealt with as the core of the storytelling in a few episodes. We used a codebook with parameters (Van Kempen 1995) that are used in the representations. The parameters we used are narrative aspects (story, characters, dialogue, space, time), the mise-en-scène (acting codes, costumes, decor, lightning), and cinematographic aspects (framing of the body, camera movement). After the first analysis of the parameters/episode, we looked for patterns in the discourses on ageing over the whole sample of all the selected episodes and we interpreted the ideological meanings of the present discourses. By unravelling the different discourses on ageing and its intersection with gender, we can distinguish three major discourses (i.e., losing femininity, masking of ageing, and the wisdom of ageing). We can differentiate discursive meanings situated within these three sets of discourses, and our analysis demonstrates that these shows articulate similar and limited sets of discourses. Besides having distinguished three sets of discourses, we found that ageing bodies are predominantly absent from the three series. 


\section{Where are the "golden girls?"}

It is important to stress that in all three series, older women either are not visible or are almost not visible. The "golden girls" thus seem to be absent. Although such women are occasionally part of the storyline, we rarely see them onscreen. When they are represented, women who are 65 or older are depicted in contrast to the younger women in the series. Ageing women are depicted as dependent, in decline, silly, and not attractive. In Girls, ageing is not one of the themes of the story, and we do not actually see ageing women and men. Ageing is stressed in a few episodes, including in the episode "Flo" (G, SO3E9) where the main character's (Hannah) grandmother is dying. Hannah reflects on her grandma as follows: "The only thing I remember about my grandma is she had really rough skin and she spit a lot." Later in the story, Hannah says, "My grandma's like, very neat, and she had skin like a kitten's ear." While on her deathbed, the grandmother says, "I am not deaf."This discourse on decay and ageing is supported by music that contains the following lyrics: "Don't let us get rich, don't let us get old." In Girls, ageing is not addressed as a key theme like it is in Desperate Housewives and Sex and the City. Still, it is a series that evolves around the friendship between four young women in their early twenties. There are similarities between Sex and the City and Girls in the way the story focuses on the lives of four young, white, and educated women in New York stressing about their single lives, relationships, sexuality, professional lives, and friendship (Driscoll and Fuller 2015; Kimberley Turner 2014).

In Desperate Housewives, one of the secondary characters, Mrs McCluskey, is older than the main characters and is depicted as different and less glamourous than the other female characters. Her body is also represented differently, and ageing is a marker for the depiction of her body. For example, her wrinkles and imperfect body are present and visible, and her non-fashionable clothes can be read as markers for the contrast in age with the other (mostly) glamourous main characters. As Jennings and Oró-Piqueras $(2016,85)$ point out, "Mrs. McCluskey's role in Desperate Housewives is in some ways the token older woman who bears the burden of representing understandings and misunderstandings of older age in Western culture." Ultimately, ageing is articulated in the way this character dies in the last season, as it is portrayed as the deterioration of her body and the loss of her femininity. Death brings the ultimate disappearance of beauty and femininity. Her role in the overall series is limited.

For example, she frequently appears as a guest star in the first five seasons and, from season six onwards, she stars but only in the episodes that she appears in. But as Jennings and Oró-Piqueras $(2016,75)$ stress, her role in the series becomes "more and more intertwined in the storylines" and "moves to a central role" (72). These "old ladies" at the margins of the storyline are often cues for humour and laughter. A similar construction can be found in The Golden Girls. As Jake Harwood and Howard Giles (1992) argue, this series is praised for presenting elderly women in a positive way; however, as their research shows, age marking and humour overlap and stereotyping of ageing femininity or the counter-stereotypes are laughable in The Golden Girls. There are some discursive ambiguities in the text, and thus The Golden Girls is not a purely positive representation of ageing femininities.

\section{Masking ageing}

Ageing seems to be omnipresent in Sex and the City, as it is part of the storyline and one of the major themes in the series. This theme is mostly embodied by the character Samantha 
who, for example, lies about her age and has celebrated her thirty-fifth birthday as long as the other characters can remember (SATC, SO2E3). Samantha is also the only one who undergoes plastic surgery, as she does not want to "look like 40" (SATC, SO2E3). In Girls, a 45-yearold woman is referred to as "someone who just got out of a bad divorce" (G, SO4E7). The discourse is also sometimes suggesting a paradox, as in Girls (G, SO1E6), for example, when we see Hannah's parents having sex in the shower, but we see repulsion through the eyes of Hannah when her father is lying naked on the bathroom floor, having suffered a concussion after falling out of the shower. The discourse around ageing in Sex and the City is contradictory and changes over the course of the episodes. For example, in one episode (SATC, SO6E12), Samantha proudly states, "I am fucking 45 and I have nothing to hide" and "I am older, not old;" at the same time, she also says "No one wants to fuck grandma." A different discourse can be found in Desperate Housewives, where secondary character Mrs McCluskey is not represented as an asexual old woman, but rather as having an active sex life. But we do not see Mrs McCluskey having sex; this act is not represented, and in this way, is masked in the sense that we cannot see it. Older people having sex is something that is not represented.

The discourse of masking ageing is often linked to the idealized culture of "agelessness" (Stephen Katz and Barbara Marshall 2003). Sex and the City can be viewed as television content constructing a representation around the notion of agelessness (for example, in the way the characters are cast and represented), but at the same time it also complicates this notion in some episodes. The shame of ageing or the denial of ageing is questioned in some episodes and seen as part of the celebration of youth in our contemporary consumer culture (Woodward 2006; Whelehan and Gwynne 2014). This masking of ageing is often signified by a discourse around "girls." As Nash and Grant $(2015,985)$ explain,

Like SATC, Girls evokes the post-feminist archetype of the modern "girls," a term that was made popular in Helen Gurley Brown's (1962 Sex and the Single Girl, which introduced the concept of an independent, urban, reflexive, and sexually active, modern woman.

Nash and Grant $(2015,986)$ point to the post-feminist "girlification" of adult women. Whelehan $(2014,43)$ examines the "possible conceptual disjunction between women growing older and women growing up, placed in the context of postfeminism's tendency to 'girl' both women and feminism."

Ageing as a part of the storyline is articulated through the theme of menopause and it is often linked to a masking discourse. In Desperate Housewives (DHW, SO7E7), for example, the character Bree has hot flashes as she experiences the onset of menopause. This theme is articulated in a storyline where she dates a younger guy and her menopause becomes even more of a problem. She denies that she is experiencing menopause and her female gynaecologist suggests that she "mask the symptoms." She then realizes that the female gynaecologist is the mother of her younger boyfriend and the one who asked the following question at a family dinner: "Is Bree the one who is going to give me my grandchildren?" At the end of this scene, the narrator says, "We may have a boyfriend, we may feel old." In Sex and the City (SATC, SO3E3), the theme is addressed in a storyline when Samantha begins to experience menopause, which is described as follows: "Her ship has sailed." Looking in the mirror, she says, "I am drying up. My time is up." Menopause seems to be equated with the materialization of ageing - an articulation of menopause that can be described as a discourse on losing femininity. 


\section{Losing femininity}

At the beginning of the first episode of the fifth season of Desperate Housewives, the narrator poses the following question: "We ask ourselves where did the time go ... How did the woman I saw each day in the mirror become someone I don't even recognize" (DHW, SO5E1)? This opening sets the tone for the episode that occurs five years after the previous episode. While clarifying the chronology, the narrator also stresses the ageing of the characters in a rather negative way by referring to "lost time" and a disconnection between the self and one's image in the mirror, implying a negative self-image due to the passing of time. This discourse is also reinforced by the visual representations of the characters, as they are less glamourous than in the previous seasons. In Sex and the City, there is a reoccurring discourse that claims that real ageing happens only when you are settled, married, and have children. In a way, characters postpone their ageing by not settling down. In both Desperate Housewives and Sex in the City, having children is equated with losing femininity and ageing rapidly. For example, in Desperate Housewives (SO5E1), the character Edie reappears in the storyline and says the following:

Edie: Do you know someone else my age with a body like this? So Gaby, I have to ask what the hell happened to you? Look at you, your clothes, your hair. Carlos may be blind, but the rest of us are not.

Gaby: I had two children.

Edie: For what, breakfast?

In this example, the discourse of ageing in relation to having children is very direct. This is a reoccurring discourse in all three series examined in this article. In Desperate Housewives, this specific discourse is present in different episodes, but mostly in regard to what having children "can do" to your body. Similarly, in Sex and the City we find a discourse on children who steal your time, your life, and therefore your body and youth. The discourse goes even further, positing the notion that youth ends when ageing starts, and that ageing starts when one has children.

In Desperate Housewives, this ageing discourse is embodied by the character Gaby when she questions the notion of ageing thusly:

She [referring to her daughter] does not know the truth yet. Women only have five seconds to be young and beautiful and then gone. And before you know it you will be old, fat, and married and you wonder where our beauty went.

This ageing discourse is also articulated in relation to marriage: once married, ageing will occur rapidly - a discourse that is also very present in Sex and the City. In Girls, while this discourse is not as direct or part of the main plotlines, it is present as a sort of future time frame that looms over the characters. In all three series, ageing will be postponed by "waiting" to get married or have children. Although some of the characters have got married and had children, the discourse and even the storylines are developed around this issue, stressing ageing as part of married life and having children. An example of this occurs in the dialogue between Gaby and her husband (who is blind in this season) in Desperate Housewives: "Sometimes I am glad that you can't see me. It has been five years, two kids, and no time for facials and fitness. It takes a toll" (DHW, SO5E1). There is also a secondary discourse on the age limit for married life. For example, in Sex and the City (SATC, SO2E3) Miranda states the following: "If a man is over 30 and single, then there is something wrong with him. What 
about us?" She thus questions their status and the options they have as single women in their thirties. In the same series (SATC, SO5E3), Charlotte looks for a husband and a family and becomes desperate in several episodes. In one episode, she is about to celebrate her thirty-fifth birthday and decides that she will be "sticking to 35." She sees herself as an old woman and highlights the gendering of age: she will become a spinster in contrast to men her age who become playboys. She is now on the "old ladies express;" no old men are present because they are "dead or married to younger girls." This is one of the rare episodes where the ageing of men is also part of the discourse.

The majority of discourses on ageing are related to femininity; men or masculinity seem to be absent in our sample. This example also highlights the difference in the representation of ageing and the gendering of how we look at ageing. The analysis of these three series reveals that the discourses on ageing do not include masculinities in our researched episodes. The discourse on losing femininity is articulated through the theme of menopause. This marker of ageing is seen as deviant. Whelehan $(2013,89)$ points out the following: "As Sandra Coney reminds us, 'Ageing in men is normal, menopause is not."'The "sexist double standard of ageing" seems to be at work. According to Rosalind Cooper (2008, 31), "The negative image of loss of sexuality and youth [...] tend to dominate references to menopause."

\section{The wisdom of ageing}

A final set of discourses signifies the idea that wisdom comes with age. Despite the fact that ageing and older men and women are either absent or hardly present in the series, there is a vague discourse around wisdom and ageing. In this discourse, masculinity seems to be absent and older women have acquired wisdom with age. For example, the narrator in Desperate Housewives could be interpreted as the "voice of older women," rather than the traditional voice of God that begins and concludes the narrative in each episode. This position of the bearer of wisdom is only found in Desperate Housewives, as embodied in the narrator. Although the character Mary Alice Young — who is only heard and never seen-is around 40 years old when she dies in the pilot episode, she is represented as "older" or ageing as the juxtaposition of "being dead" locate her in this position. This is strengthened by the use of flashbacks when referring to the past, which serve as the only visual representations of the narrator. Secondary character Mrs McCluskey can also be considered a signifying element in the discourse on female ageing and wisdom. She is an outcast and does not fit in the nucleus of the other female main characters; furthermore, while she is not part of this specific community that comprises the scope of the narrative, she has knowledge, including secrets. She can be seen as the embodiment of the "other," or what Wallander $(2013,100)$ refers to as the "old-old other." As the "other," Mrs McCluskey has more knowledge than anyone else on the show, including insight into all of the main characters' secrets. In one episode (SO3E18) she has her own secret: the dead body of her husband is stored in her freezer. According to Jennings and Oró-Piqueras (2016), ageing gives Mrs McCluskey "experiential advantages," as she is "a source of bold and wise advice to her younger women protagonists and does not sugar-coat the realities of life in her advice" (80). This discourse on the wisdom of ageing is not in the foreground of Sex and the City or Girls. However, there are very weak discursive articulations on ageing and knowledge in both series. This is reflected in opposing ways in these two series. In Girls, the wisdom of ageing is expressed when the characters reflect on the future and express the hope that wisdom will come with age. In Sex and the City, the 
opposite articulation is made when the main characters contemplate the past and conclude that being a young girl or woman comes with uncertainty, lack of experience, and so on. Although the discourses are different or even contradictory, the core of the articulation is based on the idea that being a young woman comes with lack of knowledge-and again, this lack of knowledge seems to be articulated only in relation to femininity and not in relation to masculinity.

\section{Conclusion}

At first glance, we could argue that Sex and the City, Desperate Housewives, and Girls represent a limited set of ideologies on ageing femininities. Generally, as in contemporary popular cultural texts, we can distinguish a limited set of stereotypes of ageing women. We can argue that in these post-feminist television series, not all bodies are represented as equal, nor can we claim that the discourse of "beauty is everywhere" is omnipresent. This last discourse is articulated in Girls, but it does not refer to ageing bodies. We can distinguish three sets of discourses (losing femininity, masking of ageing, and the wisdom of ageing) that seem to be present in the series. Although some scholars argue that there is a common interest in ageing because of audience-driven and economic motives, we cannot help but wonder where the "golden girls" are in contemporary television content. As Jennings and OróPiqueras $(2016,79)$ argue, there is still a "cloak of invisibility" covering ageing women on television. There has been an increase in the last five years in the representation of ageing femininities on television. However, this visibility in the episodes of three series examined in this study does not translate into bodily representations of ageing. The only exception is the representation of Hannah's parents having sex in the shower in the series Girls. But also, here we could say that a rather negative discourse is articulated by means of Hannah's reaction towards this fact. In general, we can say that while ageing feminine bodies are absent, a discourse on ageing, "good" ageing, and acceptance of ageing is present in the narration. In all three series, discourses on ageing femininities are articulated in diverse ways and the discursive space is used differently. The discourse on the masking of ageing is predominant and is a reflection of the ideology of successful ageing often embedded in a neo-liberal discourse and articulated through feminine body management. As Julie Twigg $(2004,61)$ stresses,

A range of negative meanings is read off from the aged body, which is then itself in turn taken to be the source of the problems of old age. These developments have taken place in the context of consumer culture in which the body becomes a project to be worked upon, fashioned and controlled, a site of self-identity and reflexivity, as well as of consumption.

This successful ageing is, for example, discursively constructed in Sex and the City through the girlification of some of the main characters or of femininity as such. Successful ageing is a large theme in this series, and contra-hegemonic discourses are also occasionally present. However, a dominant hegemonic reading of a glamourous anti-ageing or ageless discourse forms the core of the narration. Desperate Housewives features another discourse on ageing. In the discourse of the wisdom of ageing-as embodied by Mrs McCluskey and as thematically explored in the series - ageing is questioned, for example, by the comic relief around the embodiment of beauty (e.g., Mrs McCluskey and her mismatched clothes in contrast with the other female protagonists) or the theme of isolation and loneliness. And a critical reading of stereotypical ageing femininities is put forward. Still, we see bodily representations 
of "successful ageing" and a negative discourse on menopause as "losing femininity," which are representations of the shame of ageing. We can conclude that an ambivalent discourse on ageing femininities and an absence of ageing feminine bodies are simultaneously represented. Post-feminist television culture and its representations all include a discourse on ageing femininities. While these texts may sometimes facilitate subjectivity or the "older woman as subject-in-process" (Dolan and Tincknell 2012, xvii), they often still reproduce stereotypical discourses on ageing.

\section{Notes}

1. References indicating the season (SO) and the episode (E) will be introduced as abbreviations in parentheses. The series Sex and the City (SATC), Girls (G), and Desperate Housewives (DHW) will also be abbreviated in specific references.

2. Thanks to Frederik Dhaenens for helping out with the selection of the episodes of the series Desperate Housewives.

\section{Disclosure statement}

No potential conflict of interest was reported by the author.

\section{Notes on contributor}

Sofie Van Bauwel is an Associate Professor in Media Studies at Ghent University in Belgium. Her research interests lie in the field of gender and media and mostly include research on representation of gender and sexuality in popular media. Together with Tonny Krijnen, she is the author of Gender and Media: Representing, Producing, Consuming (2015). She is also the co-editor (with Tonny Krijnen and Claudia Alvares) of Gendered Transformations: Theory and Practices on Gender and Media (2011). E-mail: sofie. vanbauwel@ugent.be

\section{References}

Adriaens, Fien, and Sofie Van Bauwel. 2014. "Sex and the City: A Postfeminist Point of View? Or How Popular Culture Functions as a Channel for Feminist Discourse." Journal of Popular Culture 47 (1): 174-195.

Akass, Kim, and Janet Mccabe, eds. 2008. Reading Sex and the City. London: IB Tauris.

Barker, Chris. 2008. Cultural Studies: Theory and Practice. 3rd ed. London: Sage Publications.

Brasfield, Rebecca. 2006. "Rereading Sex and the City: Exposing the Hegemonic Feminist Narrative." Journal of Popular Film and Television 34 (4): 1301-1339.

Busch, Elizabeth K. 2009. "Ally McBeal to Desperate Housewives: A Brief History of the Postfeminist Heroine." Perspectives on Political Science 38 (2): 87-98.

Cooper, Rosalind. 2008. "Prime Time. TV Menopause, Queerly a Case for Review." SQS-Suomen Queertutkimuksen Seuran lehti 3 (2): 30-37.

Cuddy, Amy, Michael Norton, and Susan Fiske. 2005. "This Old Stereotype: The Pervasiveness and Persistence of the Elderly Stereotype." Journal of Social Issues 61 (2): 267-285.

Daalmans, Serena. 2013. "I'm Busy Trying to Become Who I Am': Self-Entitlement and the City in HBO's Girls." Feminist Media Studies 13 (2): 359-362.

DeCarvalho, Lauren. 2013. "Hannah and Her Entitled Sisters: (Post)feminism, (post)recession, and Girls." Feminist Media Studies 13 (2): 367-370.

Desperate Housewives. 2004-2012. Television Series. Seasons 1-8. USA: ABC/Cherry Productions.

Dionigi, Rylee, Sean Horton, and Josephine Bellamy. 2011."Meanings of Ageing Among Older Canadian Women of Varying Physical Activity Levels." Leisure Sciences 33 (5): 402-419. 
Dolan, Josephine, and Estella Tincknell, eds. 2012. Ageing Femininities: Troubling Representations. Cambridge: Cambridge Scholars Press.

Driscoll, Catherine, and Sean Fuller. 2015. "HBO's Girls: Gender, Generation, and Quality Television." Continuum. Journal of Media \& Cultural Studies 29 (2): 253-262.

Featherstone, Mike, and Mike Hepworth. 1995."Images of Positive Ageing." In Images of Ageing. Cultural Representations of Later Life, edited by Mike Featherstone and Andrew Wernick, 179-190. London and New York: Routledge.

Ford, Jessica. 2016. "The 'Smart' Body Politics of Lena Dunham's Girls." Feminist Media Studies 16 (6): 1029-1042. Accessed September 3, 2016. https://doi.org/10.1080/14680777.2016.1162826

Fuller, Sean, and Catherine Driscoll. 2015. "HBO's Girls: Gender, Generation, and Quality Television." Continuum. Journal of Media \& Cultural Studies 29 (2): 253-262. Accessed September 3, 2016. https:// doi.org/10.1080/10304312.2015.1022941

Gill, Rosalind. 2007. "Postfeminist Media Culture: Elements of Sensibility." European Journal of Cultural Studies 10 (2): 147-166.

Girls. 2012-present. Television Series. Seasons 1-4. USA: HBO.

Grace and Frankie. 2015-present. Television Series. Seasons 1-2. USA: Netflix.

Harwood, Jake, and Howard Giles. 1992."'Don't Make Me Laugh': Age Representations in a Humorous Context." Discourse Society 3 (4): 403-436.

Hant, Myrna. 2007. “Television's Mature Women. A Changing Media Archetype: From Bewitched to The Sopranos." Accessed September 18, 2016. Http://repositories.cdlib.org/cgi/viewcontent. cgi ?article $=1021 \&$ context $=$ csw

Healey, Tim, and Karen Ross. 2002. "Growing Old Invisibly: Older Viewers Talk Television." Media Culture Society 24 (1): 105-120.

Jennings, Ros, and Maricel Oro-Piqueras. 2016. "Heroine and/or Caricature? The Older Woman in Desperate Housewives." In Serializing Age: Ageing and Old Age in TV Series, Ageing Studies VII, edited by Maricel Oró-Piqueras and Anita Wohlmann, 71-89. Bielefeld: Transcript.

Katz, Stephen. 2000. "Busy Bodies. Activity, Ageing, and the Management of Everyday Life." Journal of Ageing Studies 14 (2): 135-152.

Katz, Stephen, and Barbara Marshall. 2003. “New Sex for Old: Lifestyle, Consumerism, and the Ethics of Ageing Well." Journal of Ageing Studies 17 (1): 3-16.

Kennedy, Eileen, and Pirkko Markula, eds. 2011. Women and Exercise: The Body, Health and Consumerism. New York and London: Routledge.

Kosut, Mary. 2010. "Extreme Bodies/Extreme Culture." In The Body Reader. Essential Social and Cultural Readings, edited by Lisa Jean Moore and Mary Kosut, 184-200. London and New York: New York University Press.

Kubey, Robert. 1980."Television and Ageing: Past, Present, and Future." The Gerontologist 20 (1): 16-35. Larsen, Peter. 2002."Mediated Fiction."In A Handbook of Media and Communication Research: Qualitative and Quantitative Methods, edited by Klaus Bruhn Jensen, 117-137. London and New York: Routledge.

Lövgren, Karen. 2012. "They See Themselves as Young': The Market Addressing the Older Consumer." In Representing Ageing. Images and Identities, edited by Virpi Ylänne, 53-67. Houndsmills: Palgrave Macmillan.

Low, Jacqueline, and Suzanne Dupuis-Blanchard. 2013. "From Zoomers to Geezerade: Representations of the Aging Body in Ageist and Consumerist Society." Societies 3 (1): 52-65.

Marchal, Barbara, and Stephen Katz. 2012. "The Embodied Life Course: Post-Ageism or the Renaturalization of Gender?" Societies 2 (3): 222-234.

McKee, Alan. 2003. Textual Analysis: A Beginner's Guide. London: Sage.

McRobbie, Angela. 2004. "Post-Feminism and Popular Culture." Feminist Media Studies 4 (3): 256-264.

Nash, Meredith, and Ruby Grant. 2015. "Twenty-Something Girls v. Thirty-Something Sex and the City Women. Paving the Way for 'Post? Feminism.' Feminist Media Studies 15 (6): 976-991.

One Foot in the Grave. 1990-2000. Television Series. Season 1-6. GB: BBC.

Oró-Piqueras, Maricel, and Anita Wohlmann, eds. 2015. Serializing Age: Ageing and Old Age in TV Series. Bielefeld: Transcript Verlag.

Perkings, Claire. 2014. “Dancing on My Own: Girls and Television of the Body Critical Studies." Television: The International Journal of Television Studies 9 (3): 33-43. 
Rockler, Naomi. 2006. "'Be Your Own Windkeeper': Friends, Feminism, and Rhetorical Strategies of Depoliticization." Women's Studies in Communication 29 (2): 244-264.

Ronzanova, Julia. 2010. "Discourse of Successful Aging in The Globe \& Mail: Insights from Critical Gerontology." Journal of Aging Studies 24 (4): 213-222.

Sex and the City. 1998-2004. Television Series. Season 1-6. USA: HBO.

Synnot, Anthony. 2002. The Body Social. London: Routledge.

Talley, Heather L. 2013. Saving Face. Disfigurement and the Politics of Appearance. New York: NYU Press. Tasker, Yvonne, and Diane Negra. 2007. Interrogating Postfeminism: Gender and the Politics of Popular Culture. Durham, NC: Duke University Press.

The Golden Girls. 1985-1992. Television Series. Seasons 1-7. US: NBC.

Turner, Kimberly. 2014. "Queering the Single White Female: Girls and the Interrupted Promise of the Twenty-something." In HBO's Girls: Question of Gender, Politics and Millennial Angst, edited by Betty Kaklamanidou and Margaret Tally, 156-171. Newcastle upon Tyne: Cambridge Scholars Publishing.

Twigg, Julie. 2004. "The Body, Gender, and Age: Feminist Insights in Social Gerontology." Journal of Ageing Studies 18 (1): 59-73.

Van Kempen, Johan. 1995. Geschreven op het scherm: Een methode voor filmanalyse [Written on the screen: A method for film analysis]. Utrecht: LOKV.

Wallander, Kristina. 2013. "Successful Images of Successful Ageing? Representations of Vigorous Elderly People in a Swedish Educational Television Programme." Nordicom Review 34 (1): 91-103.

Wearing, Sadie. 2012. "Exemplary or Exceptional Embodiment?: Discourses of Ageing in the Case of Helen Mirren and 'Calendar Girls.' In Ageing Femininities: Troubling Representations, edited by Josephine Dolan and Estella Tincknell, 145-159. Cambridge: Cambridge Scholars Press.

Wearing, Sadie. 2015. "Moms Mabley and Whoopi Goldberg: Age, Comedy and Celebrity." In Women, Celebrity and Cultures of Ageing: Freeze Frame, edited by Deborah Jermyn and Susan Holmes, 59-76. London: Palgrave Macmillan.

Whelehan, Imelda. 2010. "Remaking Feminism: Or Why is Postfeminism So Boring?" Nordic Journal of English Studies 9 (3): 155-172.

Whelehan, Imelda. 2013. "Ageing Appropriately: Postfeminist Discourses of Ageing in Contemporary Hollywood." In The Palgrave Macmillan Postfeminism and Contemporary Hollywood Cinema, edited by Joel Gwynne and Nadine Muller, 78-95. Basingstoke: Springer.

Whelehan, Imelda, and Joel Gwynne. 2014. "Introduction: Popular Culture's 'Silver Tsunami".' In Ageing, Popular Culture and Contemporary Feminism. Harleys and Hormones, edited by Imelda Whelehan and Joel Gwynne, 1-13. Basingstoke: Palgrave Macmillan.

Whelehan, Imelda. 2014. "Fiction or Polemic? Transcending the Ageing Body in Popular Women's Fiction." In Ageing, Popular Culture and Contemporary Feminism. Harleys and Hormones, edited by Imelda Whelehan and Joel Gwynne, 29-46. Basingstoke: Palgrave Macmillan.

White, Rosie. 2014. "Funny Old Girls: Representing Older Women in British Television Comedy." In Ageing, Popular Culture and Contemporary Feminism. Harleys and Hormones, edited by Imelda Whelehan and Joel Gwynne, 155-171. Basingstoke: Palgrave Macmillan.

Woodward, Kathleen. 2006. "Performing Age, Performing Gender." National Women's Studies Assoc. Journal 18 (1): 162-189.

Ylänne, Virpi, eds. 2012. Representing Ageing: Images and Identities. Houndsmills: Palgrave Macmillan. 